Thorax (1972), 27, 591.

\title{
Haemodynamic effects of glucagon after mitral valve replacement
}

\author{
G. H. SMITH and K. CHANDRA \\ Sheffield Cardio-thoracic Unit, Northern General Hospital, Sheffield S5 7AU
}

\begin{abstract}
We have studied six patients who had undergone mitral valve replacement. Estimations of cardiac output and of pulmonary vascular resistance were made, beginning two hours after the finish of the operation. Glucagon, $10 \mathrm{mg}$, was given intravenously, and cardiac output and pulmonary vascular resistance were measured 5 minutes and 30 minutes later. In all six cases there was a significant decrease in pulmonary vascular resistance and this occurred whether the resistance was slightly, moderately or greatly elevated. There was a highly significant increase in cardiac output in all cases.
\end{abstract}

In the last 10 years the action on the cardiovascular system of the pancreatic hormone, glucagon, has been demonstrated repeatedly. We have studied the action of glucagon in six patients who have undergone mitral valve replacement.

\section{PATIENTS AND METHODS}

Six patients who had undergone mitral valve replacement were studied. In two cases aortic valve replacement had been performed as well. At operation cannulae were routinely placed in the right and left atria and also in the radial artery at the wrist. In these cases a fine plastic cannula was introduced into the pulmonary artery before closure of the chest. A small purse string suture of $4 / 0$ non-absorbable material was inserted into the epicardium of the infundibulum of the right ventricle. A small incision was then made in the epicardium with a fine scalpel. A blunt serum needle was pushed through into the cavity of the right ventricle, and the plastic cannula was threaded through it and advanced into the main pulmonary artery. The serum needle was withdrawn and the purse string suture tied. Using a sharp serum needle introduced from outside, the cannula was inserted through the anterior chest wall, usually at the fifth intercostal space on the left. The cannula was connected to the pressure recording system using a Tuohy connector.

The study was begun two hours after the finish of the operation. Mean left atrial pressures were measured in centimetres of water by a hydrostatic method. The values obtained were then converted to millimetres of mercury by dividing by 13.56 . Mean pulmonary artery pressures were measured using a Bell and Howell transducer connected to a Cambridge multi-channel photographic recording apparatus. Measurements of mean pulmonary artery pressure were recorded in millimetres of mercury.
Cardiac output was estimated by the dye dilution technique using an injection of $5 \mathrm{ml}$ of indocyanine green into the right atrial cannula and sampling into a Gilford densitometer from the radial artery at the wrist using a Harvard withdrawal pump.

Mean left atrial and pulmonary artery pressures and the cardiac output were measured in the resting state and at 5 minutes and 30 minutes after the intravenous injection of $10 \mathrm{mg}$ of glucagon (Glucagon, Eli Lilly). The pulse rate and electrocardiogram were observed in order to detect any dysrhythmias.

The pulmonary vascular resistance at each estimation was calculated as follows:

Pulmonary vascular resistance in units

(Mean PA pressure in mmHg)-(Mean LA pressure in $\mathrm{mmHg}$ ) Cardiac output in litres per minute

The figure obtained was multiplied by 80 in order to express the pulmonary resistance in fundamental physical units (dynes $/ \mathrm{sec} / \mathrm{cm}^{-5}$ ).

At the conclusion of the study the pulmonary artery catheter was withdrawn. In no case did bleeding occur nor was any difficulty encountered.

The results obtained in the resting state and at 5 and 30 minutes were subjected to the paired $t$ test.

\section{RESULTS}

During the period of observation each patient had a stable arterial blood pressure and showed no change in any other clinical index of cardiac output. No dysrhythmias occurred.

Table I shows the variations in mean pulmonary artery pressure, mean left atrial pressure, and cardiac output in each patient studied.

Table II shows the variations in the calculated pulmonary vascular resistance (expressed in dynes / $\mathrm{sec} / \mathrm{cm}^{-5}$ ) in each patient during the period of the study. The change in pulmonary vascular 
T A B LE I SUMMARY OF CHANGES IN PRESSURES IN PULMONARY ARTERY AND LEFT ATRIUM AND CARDIAC OUTPUT AFTER
INJECTION OF $10 \mathrm{mg}$ GLUCAGON I.V.

\begin{tabular}{|c|c|c|c|c|c|c|c|c|c|c|c|c|c|c|}
\hline \multirow[b]{2}{*}{$\begin{array}{c}\text { Patient } \\
\text { Sex/Age }\end{array}$} & \multirow[b]{2}{*}{$\begin{array}{c}\text { Opera- } \\
\text { tion }\end{array}$} & \multirow[b]{2}{*}{$\begin{array}{c}\text { Preop. } \\
\text { PA } \\
\text { (mmHg) }\end{array}$} & \multicolumn{4}{|c|}{ Resting State } & \multicolumn{4}{|c|}{5 min after Glucagon } & \multicolumn{4}{|c|}{30 min after Glucagon } \\
\hline & & & \begin{tabular}{|c|} 
PA \\
Mean \\
Pressure \\
$(\mathrm{mmHg})$
\end{tabular} & $\begin{array}{c}\text { LA } \\
\text { Mean } \\
\text { Pressure } \\
\text { (mmHg) }\end{array}$ & $\begin{array}{l}\text { Cardiac } \\
\text { Output } \\
(1 / \mathrm{min})\end{array}$ & $\begin{array}{c}\text { PVR } \\
\text { (dynes/ } \\
\text { sec/ } \\
\mathrm{cm}^{-5} \text { ) }\end{array}$ & $\begin{array}{c}\text { PA } \\
\text { Mean } \\
\text { Pressure } \\
(\mathrm{mmHg}) \\
\end{array}$ & $\begin{array}{c}\text { LA } \\
\text { Mean } \\
\text { Pressure } \\
\text { (mmHg) } \\
\end{array}$ & $\begin{array}{l}\text { Cardiac } \\
\text { Output } \\
\text { (1/min) }\end{array}$ & $\begin{array}{c}\text { PVR } \\
\text { (dynes/ } \\
\text { sec/ } \\
\mathrm{cm}^{-5} \text { ) }\end{array}$ & $\begin{array}{c}\text { PA } \\
\text { Mean } \\
\text { Pressure } \\
\text { (mmHg) }\end{array}$ & \begin{tabular}{|c|} 
LA \\
Mean \\
Pressure \\
(mmHg)
\end{tabular} & $\begin{array}{l}\text { Cardiac } \\
\text { Output } \\
\text { (1/min) }\end{array}$ & $\begin{array}{c}\text { PVR } \\
\text { (dynes/ } \\
\text { sec/ } \\
\mathrm{cm}^{-5} \text { ) }\end{array}$ \\
\hline 1 & & & & & & & & & & & & & & \\
\hline $\begin{array}{c}F \quad 36 \\
2\end{array}$ & MVR & $\begin{array}{l}40 \\
20\end{array}$ & 16 & 10 & $3 \cdot 3$ & 144 & 15 & 12 & $3 \cdot 8$ & 63 & 20 & 14 & $3 \cdot 9$ & 124 \\
\hline $\begin{array}{c}M 44 \\
3\end{array}$ & MVR & $\begin{array}{l}80 \\
40\end{array}$ & 38 & $10 \cdot 5$ & $3 \cdot 3$ & 667 & 38 & 14 & $3 \cdot 8$ & 506 & 40 & $12 \cdot 5$ & $3 \cdot 9$ & 564 \\
\hline $\begin{array}{c}M \quad 45 \\
4\end{array}$ & MVR & $\begin{array}{l}25 \\
10\end{array}$ & 20 & $10 \cdot 5$ & $2 \cdot 0$ & 580 & 24 & 14 & $3 \cdot 4$ & 235 & 30 & $15 \cdot 5$ & $3 \cdot 8$ & 295 \\
\hline $\begin{array}{ll}\text { F } & 59 \\
& 5\end{array}$ & $\begin{array}{c}\text { AVR } \\
\text { MVR }\end{array}$ & $\begin{array}{l}45 \\
10\end{array}$ & 16 & 11 & $2 \cdot 7$ & 148 & 16 & 13 & $3 \cdot 2$ & 75 & 15 & 11 & $3 \cdot 13$ & 102 \\
\hline $\begin{array}{c}\text { M } 35 \\
6\end{array}$ & $\begin{array}{c}\text { AVR } \\
\text { MVR }\end{array}$ & $\begin{array}{l}45 \\
25\end{array}$ & $13 \cdot 5$ & $6 \cdot 5$ & $2 \cdot 44$ & 440 & 20 & $7 \cdot 5$ & $3 \cdot 0$ & 334 & 20 & $6 \cdot 5$ & $3 \cdot 1$ & 350 \\
\hline F 36 & MVR & $\begin{array}{l}20 \\
10\end{array}$ & 25 & $13 \cdot 5$ & 3.69 & 248 & 26 & 16 & 3.90 & 203 & 27 & $13 \cdot 5$ & $4 \cdot 27$ & 252 \\
\hline
\end{tabular}

T A B LE I I

CHANGES IN PULMONARY VASCULAR RESISTANCE DURING THE STUDY

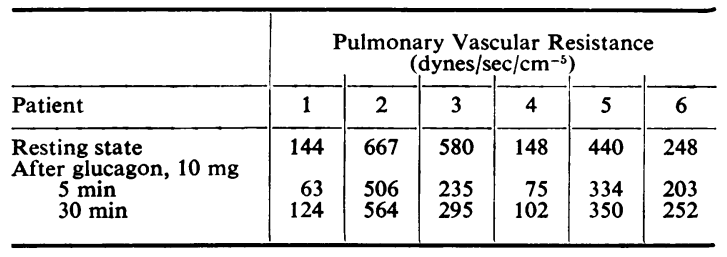

T A B L E I I I

CHANGES IN CARDIAC INDEX AFTER INJECTION OF $10 \mathrm{mg}$ GLUCAGON

\begin{tabular}{l|c|c|c|c|c|c}
\hline & \multicolumn{5}{|c|}{ Cardiac Index $\left(1 / \mathrm{min} / \mathrm{m}^{2}\right)$} \\
\hline Patient & 1 & 2 & 3 & 4 & 5 & 6 \\
\hline Resting & 2.00 & 1.95 & 1.20 & 1.60 & 1.20 & 2.37 \\
$\begin{array}{l}\text { After glucagon } \\
\text { 5 min } \\
\text { 30 min }\end{array}$ & 2.36 & 2.26 & 2.00 & 1.95 & 1.52 & 2.5 \\
\hline
\end{tabular}

resistance after the injection of glucagon is significant at the $\mathbf{P}=0.05$ level for the resting and 5 -minute values, and for the 5- and 30-minute values.

Table III shows the variation in cardiac index (expressed in $1 / \mathrm{min} / \mathrm{m}^{2}$ ) in each patient during the same time. The resting cardiac index was significantly increased 5 minutes after administration of glucagon compared with the resting values $(\mathbf{P}<0.01)$. No statistical difference was detected between the cardiac indices at 5 minutes and at 30 minutes after glucagon.

\section{DISCUSSION}

A prolonged period of low cardiac output com $-\stackrel{\frac{\Phi}{2}}{\Rightarrow}$ monly occurs after mitral valve replacement and is a cause of mortality and morbidity. The low output is often attributed to the presence of pulmonary vascular disease since it more commonly occurs in patients with high pulmonary vascular $\overrightarrow{\vec{\sigma}}$ resistance before operation (Rouleau, Frye, and Ellis, 1969).

The pulmonary vascular lesions have been described (Harris and Heath, 1962) and are the result of prolonged pulmonary venous hyperten- $\frac{3}{3}$ sion consequent upon the mitral valve disease. 0 Successful replacement of the mitral valve has been shown to produce a fall in the pulmonary $\frac{7}{0}$ vascular resistance in the months that follow. (Braunwald, Braunwald, Ross, and Morrow, $\mathcal{N}$ 1965), but in severely affected patients, the im- N pairment of cardiac output may be such as to cause the death of the patient in the early postoperative hours or days.

Glucagon has been known for some years to

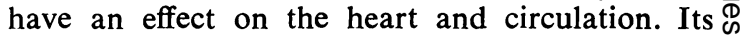
action has been studied in isolated cardiac muscle? (Farah and Tuttle, 1960), in heart lung prepara- 0 tions, and in intact animals (Regan et al., $1964 ; \underset{\mathbb{D}}{\stackrel{\circ}{\Phi}}$ Glick, Parmley, Weschler, and Sonnenblick, $1968 ; \frac{?}{\mathbb{D}}$ Lucchesi, 1968). The actions have been studied in $\varnothing$ man in health and disease (Klein, Morch, and 
Mahon, 1968; Linhart et al., 1968; Williams, Childress, Chip, and Border, 1969; Lal and Fletcher, 1969 ; Murtagh et al., 1970).

In all reports a rise of cardiac output and stroke volume has been shown. The rate of contraction of the myocardium has been increased and the peripheral vascular resistance has usually fallen. Some observers have noted a tachycardia. No dysrhythmia apart from this seems to occur, however, and the only side effect noted has been nausea.

We know of no work which has measured the effect of glucagon on the pulmonary vascular resistance. The cardiac actions of glucagon are thought to be due to the release of adenyl cyclase which increases cellular energy production. The effects of glucagon on carbohydrate metabolism have been measured by Klein et al. (1968), the blood glucose showing a progressive rise during the period of their study. Other authors (Linhart et al., 1968; Murtagh et al., 1970) noted only a transient rise in blood glucose. The last observers noted increased cardiac output in patients with rheumatic mitral valve disease.

Our study has shown a consistent increase in cardiac output after the administration of glucagon in patients who have undergone mitral valve replacement. We have demonstrated that the pulmonary vascular resistance fell. This decrease occurs in patients with mild, moderate, and severe elevations of the pulmonary vascular resistance. It is possible, however, to argue that the decrease in pulmonary resistance is merely a normal physiological response to an increased cardiac output. Difficulty also arises in explaining the action, if any, of glucagon on the pulmonary arterioles and venules.

Nevertheless we have shown that the calculated pulmonary vascular resistance falls even in the presence of severe pulmonary vascular disease, and it is in these cases that the lesions in the vessel walls would be widespread and possibly render the vessel incapable of reacting in a physiological manner. We plan to conduct a further study to assess the effect on the pulmonary resistance of variations in the cardiac output alone.

Meanwhile glucagon commends itself as an effective drug for increasing cardiac output after valve replacement without the induction of dysrhythmias.

\section{REFERENCES}

Braunwald, E., Braunwald, N. S., Ross, J., and Morrow, A. G. (1965). Effects of mitral-valve replacement on the pulmonary vascular dynamics of patients with pulmonary hypertension. New Eng. J. Med., 273, 509.

Farah, A. and Tuttle, R. (1960). Studies on the pharmacology of glucagon. J. Pharmacol. exp. Ther., 129, 49.

Glick, G., Parmley, W. W., Wechsler, A. S., and Sonnenblick, E. H. (1968). Glucagon-its enhancement of cardiac performance in the cat and dog and persistence of its inotropic action despite beta-receptor blockade with propranolol. Circulat. Res., 22, 789.

Harris, P., and Heath, D. (1962). Human Pulmonary Circulation, chapter 19. Livingstone, Edinburgh and London.

Klein, S. W., Morch, J. E., and Mahon, W. A. (1968). Cardiovascular effects of glucagon in man. Canad. med. Ass. J., 98, 1161.

Lal, S., and Fletcher, E. (1969). Glucagon therapy in heartfailure. Lancet, 1, 731.

Linhart, J. W., Barold, S. S., Cohen, L. S., Hildner, F. J., and Samet, P. (1968). Cardiovascular effects of glucagon in man. Amer. J. Cardiol., 22, 706.

Lucchesi, B. R. (1968). Cardiac actions of glucagon. Circulat. Res., 22, 777.

Murtagh, J. G., Binnion, P. F., Lal, S., Hutchison, K. J., and Fletcher, E. (1970). Haemodynamic effects of glucagon. Brit. Heart. J., 32, 307.

Regan, T. J., Lehan, P. H., Henneman, D. H., Behar, A., and Hellems, H. K. (1964). Myocardial metabolic and contractile response to glucagon and epinephrine. J. Lab. clin. Med., 63, 638.

Rouleau, C. A., Frye, R. L., and Ellis, F. H. (1969). Hemodynamic state after open mitral valve replacement and reconstruction. J. thorac. cardiovasc. Surg., 58, 870.

Williams, J. F., Childress, R. H., Chip, J. N., and Border, J. F. (1969). Hemodynamic effects of glucagon in patients with heart disease. Circulation, 39, 38. 